\title{
OCUPAÇÃO DO LEITO MAIOR DO RIBEIRÃO CLARO POR HABITAÇÕES
}

\author{
José Humberto Barcelos \\ Pompeu Figueiredo de Carvalho \\ Cláudio Antonio de Mauro
}

Profs. Drs. do Laboratório de Planejamento Municipal - UNESP - Rio Claro

RESUMO: O Leito Maior ("várzea") do Ribeirão Claro, em Rio Claro-SP, vem sendo entulhado com resíduos, tais como lixo de postos de gasolina e oficinas mecânicas, entulhos de construção civil, podas de vegetação, entre outros. Sobre esse aterro improvisado estão sendo construídas trinta e seis (36) casas populares do Projeto Pé-no-Chão, pelo sistema trava-blocos, no Jardim Conduta. No local existe uma faixa sujeita a inundação, preenchida por aluviōes recentes, resultantes das deposições fluviais e secundariamente do escoamento pluvial proveniente dos interflúvios. Do topo do interflúvio até o canal fluvial, pela margem esquerda, registra-se um desnível topográfico próximo dos 150 metros, devido às diferenças geológicas decorrentes do afloramento de um "sill" de diabásio e a planície de inundação. As habitações estão sendo erguidas pela margem direita, dentro da área inundável, aterrada. Com o desnivel topográfico, o escoamento da água pluvial tende a acarretar elevadas perdas de solo por lixiviação horizontal, proporcionando também condições para abertura de formas erosivas lineares, a exemplo de vossorocas. A vegetação aterrada pelos resíduos, exercia um papel moderador para a ação erosiva, tornando-se assi, indispensável sua preservação para manutenção das condições que vigiam no sistema das vertentes e no leito fluvial. Sabe-se que a proteção do Leito Maior que caracteriza a Área de Preservação Permanente é prevista pelas Legislações Federal, Estadual e pelo Plano Diretor de Desenvolvimento de Rio Claro. A área que apresentava canais fluviais e setores alagados, do tipo pantanoso foi aterrada, e em consequência disto o Leito Maior do Ribeirão Claro ficou diminuído e confinado. Destarte, pela necessidade de expandir suas águas de cheias, o canal fluvia, não respeitará os limites impostos pelo aterro. Nos períodos de cheias, as águas de transbordamento deverão atingir as habitações e as ruas, carreando ainda efluentes urbanos (doméstico, industrial e hospitalar) lançados no canal fluvial advindo, em consequência, doenças de veiculação hídrica, bem como as decorrentes de períodos pós- enchentes. Analisada técnica e legalmente, a alternativa para resolver esta importante questão é reabilitar o meio ambiente, removendo as casas, sem prejuízos financeiros dos proprietários, que deverão ter seus gastos ressarcidos. Como algumas das residências do Projeto estão habitadas, seria necessária a construção de casas em locais apropriados, transferindo essas familias, antes dos riscos das enchentes. A remoção do aterro e reabilitação da Área de Preservação Permanente são encaminhamentos obrigatórios por força das Leis. Essas providências evitarão os problemas resultantes de inundações, com todas as nefastas consequências para as famílias residentes e para o meio ambiente.

Palavras Chaves: leito maior; inundações; degradação ambiental; habitação meio ambiente; área de preservação permanente.

ABSTRACT: This essay is about a local governmental social housing project located in the meadows of the Ribeirão Claro in the urban area of Rio Claro, a medium-sized town in the interior of São Paulo State - Brasil. First, the meadows were inadequately used, according to Brasilian Laws, as building waste (but domestic and industrial waste were witnessed) disposal site. That area, formed by recent fluvial deposits is liable to constant floods. The level of the left watershed is about 150 meters because of geologic features and due to a "still" diabasium raising and flood plain. This topographical feature implies a constant erosion process in the right margin aggravated by the destruction of vegetation that had the function of slowing the flood streams. That situation was made worse by building waste disposal that impedes 
waterflow int this enlarged channel. A consequent landfill was carried out to build the housing scheme, worsening further the situation. All these irrational and irreversible actions which features a complete mismanagement of environment was made without any respect of Brazilian laws at different levels and instances of government, including the Rio Claro Municipal Developmente Master Plan. The overall water stream system (including the "smallchannel", the "large channel" and flood plains) has being reduced to its "small channel" with serious and critical consequences to environment (upwards and downwards) and to the housing estate and their residents. Furthermore, the consequences will reach residential blocks built in the adjacent terraces. The dwellers of this expanded area will be liable to floods and watervector diseases once the problems of sewage, urban drainage, and waste disposal are still unsolved by the concerned authorities. The only to solve, legally, socially, and technically, the overall issue is to promote the rehabilitation of environment and preserve the rights of the dwellers to appropriate housing.

Key Words: large Channel, floods, environmental degradation, housing and environment, environment areas.

\section{INTRODUÇÃO}

A partir dos últimos meses de 1994, a Prefeitura Municipal de Rio Claro (SP) iniciou a construção de casas populares, no sistema de trava-blocos, cujo Projeto é denominado Pé-noChão. Em geral, as áreas escolhidas para a implantação das residências apresentam problemas de localização, como por exemplo: nas bordas do Horto Florestal, no Bairro São Miguel; às margens do rio Corumbataí, no Bairro Bela Vista (Nosso Teto); e no Leito Maior ("várzea") do Ribeirão Claro, no Jardim Conduta (FOTOGRAFIA 1). Este trabalho diz respeito às atividades desenvolvidas no Jardim Conduta.
O Ribeirão Claro tem suas nascentes no município de Rio Claro e suas águas são captadas para abastecimento urbano. É afluente do Rio Corumbataí, que por sua vez deságua no Rio Piracicaba.

Grande parte das áreas do Jardim Conduta é alagada e/ou pantanosa, e está sendo entulhada com resíduos das mais variadas origens, provenientes de postos de gasolina, materiais de construção, podas de vegetação, lixo doméstico, entre outros, com aquiescência da Prefeitura Municipal de Rio Claro. Sobre o aterro improvisado estão sendo edificadas trinta e seis (36) casas

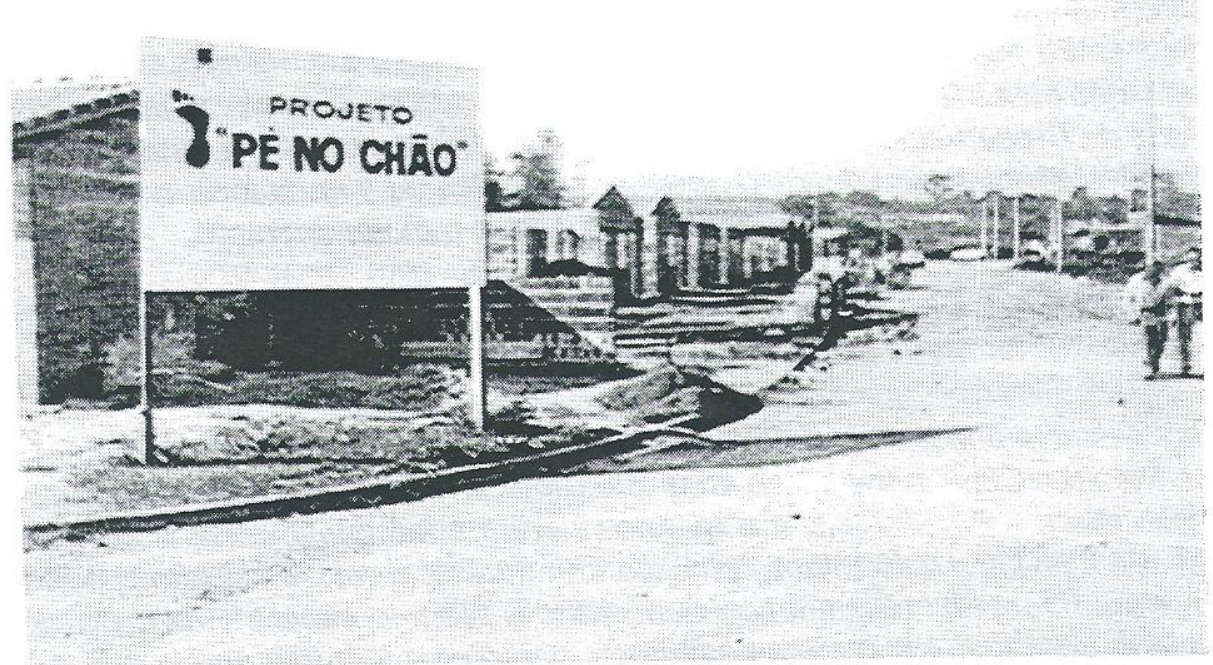

FOTO 1 - Primeiras construç̄es do Projeto Pé-noChāo, na área aterrada pertencente ao Leito Maior do Ribeirão Claro, onde se localizava uma lagoa, anteriormento ao aterro. A placa demonstra a responsabilidade da Prefeitura Municipal, com participações diretas das: Secretaria Municipal de Obras; Secretaria Municipal de Desenvolvimento, Planejamento e Meio Ambiente; e, Secretaria Municipal da Ação Social. Posteriormente foi criada e administra as obras a Secretaria Municipal de Habitação. 
populares do Projeto Pé-no-Chão. Diversos são os problemas construtivos observados nas unidades habitacionais, como por exemplo: falta de base adequada para as casas e paredes desalinhadas, entre outros. Contudo, as questões discutidas neste trabalho referem-se à ocupação indevida da Área de Preservação Permanente e à agressão praticada contra o meio ambiente, ferindo postulados de leis maiores do Plano Diretor de Desenvolvimento do Município, além dos princípios éticos e humanos mais elementares.

\section{A ÁREA E O PROBLEMA}

Para localizar o assunto será feita uma breve descrição da área, levando em conta o que afirmou a União Internacional Para a Conservação da Natureza Programa das Nações Unidas Para o Meio Ambiente \& Fundo Mundial Para a Natureza (1992), em CUIDANDO DO PLANETA TERRA: "A vida no Planeta Terra depende da água, porém o mau controle das águas está reduzindo a produtividade agrícola, espalhando doenças e colocando em perigo o equilíbrio ecológico."

As obras do Projeto Pé-no-Chão localizamse no Jardim Conduta em uma área cujo Perfil Topolito-pedológico está apresentado na FIGURA 1 . O perfil demonstra que pela margem esquerda do Ribeirão Claro existe uma pequena faixa de planície fluvial, preenchida por aluviões recentes. Essas aluviões são resultantes das deposições efetuadas pelo canal fluvial e secundariamente pelo escoamento pluvial, proveniente dos interflúvios. Em sua continuidade (W-E), há afloramentos de rochas paleozóicas, referentes à Formação Corumbataí, com predomínio de argilitos e siltitos, conforme demonstra o Mapa Geológico elaborado por ZAINE (1995). A área referida é seguida por diabásios da Formação Serra Geral, que sustenta o sill denominado Morro do Horto. Deve-se destacar que, no perfil, as espessuras dos pacotes sedimentares, bem como os contatos subsuperficiais e de profundidade estão assinalados de maneira esquemática. É notável observar-se que em uma distância aproximada de 800 metros, desde as Antenas de Retransmissão de TV, localizadas no topo do Morro do Horto, até a margem esquerda do Ribeirão Claro, há desníveis topográficos de aproximadamente 150 metros. Isto equivale a um desnível médio de 1 metro para cada 5 metros de percurso. A característica impermeabilizante, tanto das rochas que embasam o referido morro, quanto da Formação Corumbataí, estimula o escoamento superficial das águas pluviais em percentuais elevados. Com desníveis de tanta expressão, o escoamento da água pluvial tenderia a acarretar elevadas perdas por lixiviação do solo, oferecendo também boas condições para a abertura de formas lineares de erosão, a exemplo de vossorocas. Contudo, a vegetação de eucaliptos do Horto Florestal e a mata ciliar (Vegetação de Preservação Permanente) existente nas margens do Ribeirão Claro exercem importante papel moderador para a ação erosiva. Pode-se afirmar que a preservação dessa vegetação existente ao longo do canal fluvial torna-se indispensável para a manutenção das condições vigentes no Horto Florestal e no canal do Ribeirão Claro.

A partir da margem direita do Ribeirão Claro as condições são diferentes. O Perfil Topo-litopedológico (FIGURA 1) demonstra que os desníveis topográficos são de menor expressão. Também a litologia é diferente daquela descrita para a margem esquerda. Pela margem direita a planície fluvial e, portanto, o Leito Maior do Ribeirão Claro, ganha maiores extensões, com cerca de 120 metros. Em seguida, após o Leito Maior, há pequenos aclives onde predominam os pacotes sedimentares de areias, argilas e conglomerados da Formação Rio Claro. A Formação Rio Claro é composta por sedimentos pouco consolidados, amplamente suscetíveis à ação erosiva. É sobre essa formação geológica que se erguem, predominantemente (não somente sobre ela), os edifícios construídos na área urbana de Rio Claro - o Mapa Geológico apresentado por ZAINE, (op. cit.) confirma esta afirmação. A partir da margem direita até o local onde se colocam os trilhos da Companhia Paulista (FEPASA), os desníveis topográficos (FIGURA 1), variam em aproximadamente 20 metros, ou seja, para que se tenha um desnível de 1 metro, há que se caminhar cerca de 15 metros. Os níveis de impermeabilização impostos pelas edificações, asfaltamentos de ruas e outros sobre a Formação Rio Claro contribuem decisivamente para a diminuição de infiltração e para o aumento do escoamento superficial das águas pluviais, acelerando a erosão nas margens do Ribeirão Claro. O conjunto de fatores abordados torna indispensável a manutenção das grandes extensões do Leito Maior do Ribeirão Claro, para que as águas das chuvas tenham espaços de armazenamento e dissipação de energia. 


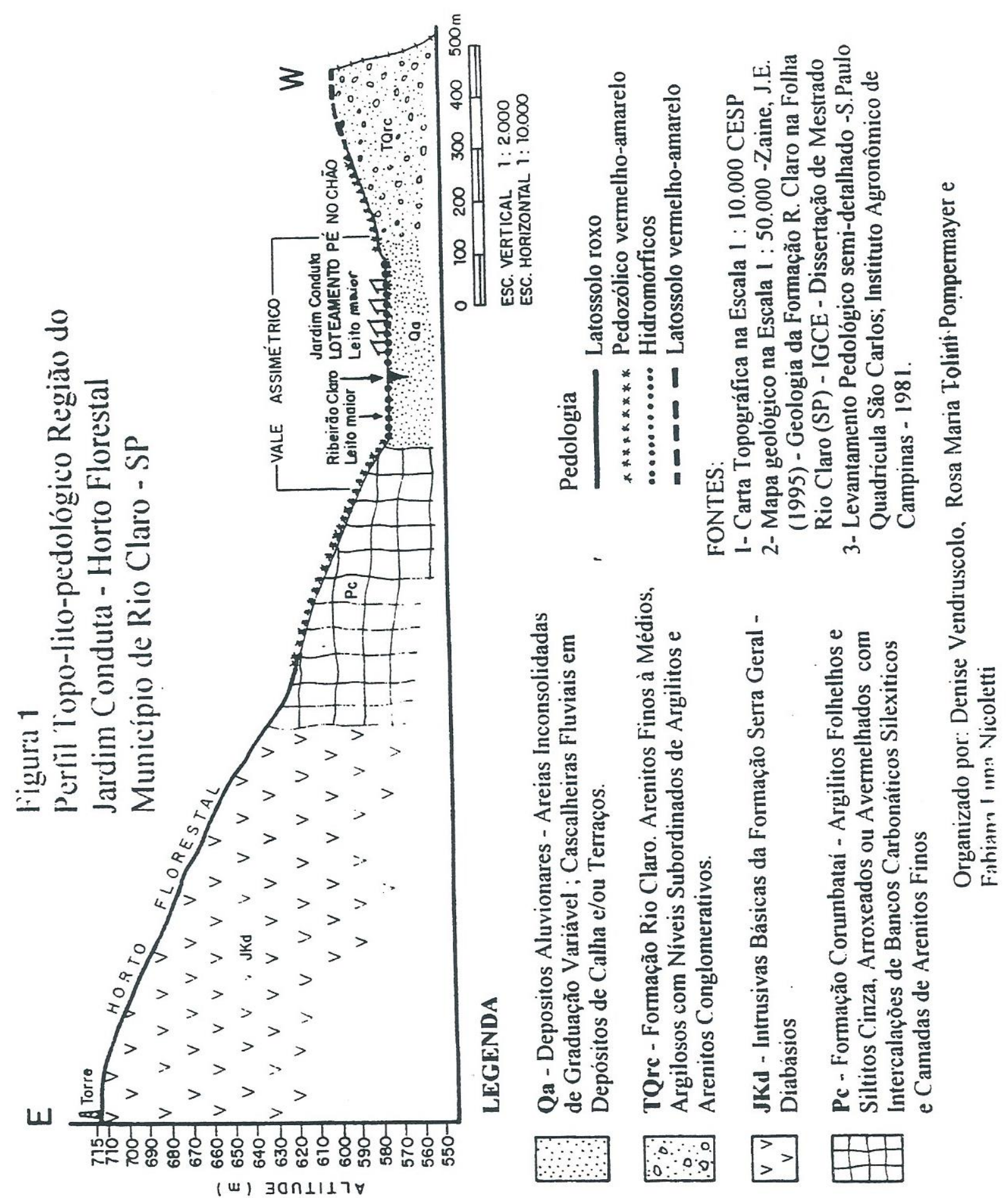


A proteção do Leito Maior que caracteriza toda a Área de Preservação Permanente prevista pela Legislação Federal e mesmo pelo Plano Diretor de Desenvolvimento de Rio Claro não se caracteriza por um ato isolado, sem fundamentação técnica. É interessante observar-se que a Lei 4.771 , de setembro de 1965 (com as alterações da Lei 7.803 , de 18 de julho de 1989), conhecida como Código Florestal, reconhece a atribuição do município para elaborar seu Plano Diretor, seus projetos e leis de uso do solo. Entretanto, no Parágrafo Único de seu Artigo Segundo, afirma: "No caso de áreas urbanas, assim entendidas as compreendidas nos perímetros urbanos definidos por lei municipal, e nas regiões metropolitanas e aglomerações urbanas, em todo o território abrangido, observar-se-á o disposto nos respectivos planos e leis de uso do solo, respeitados os princípios e limites a que se refere este artigo.". Portanto, o Código Florestal apresenta os limites mínimos para o Município respeitar em seus planos e leis. O Município poderá ampliar os limites previstos na Lei Federal, para as Áreas de Preservação Permanente, nunca diminuí-los.

Não bastasse o papel desempenhado pela Área de Preservação Permanente voltado para as qualidades de água, vegetação e fauna, bem como para a dissipação de energia erosiva, a legislação reconhece sua importância como agente de regulação da vazão fluvial, consequentemente das cheias, preservadora das condições sanitárias para o desenvolvimento da vida humana nas cidades. Com isto, pode-se afirmar que as Áreas de Preservação Permanente devem ser mantidas em suas características originais, reconhecidas como indispensáveis para a manutenção das bacias hidrográficas e, por conseqüência, da vida humana e seu desenvolvimento.

Para COOKE \& DOORNKAMP (1990), todas as vezes que se exercer um impacto local, construindose nas áreas de inundação fluvial, há consequências e impactos regionais. Para os autores referidos, mesmo quando são indispensáveis as construções em uma área de inundação e/ou alagamento, há que se fazer estudos de identificação para se estimar a descarga fluvial, a influência nas planícies de inundação, bem como as interrelações entre os níveis de vazão e as áreas de tranbordamentos. No caso do Projeto Pé-no-Chão, no Jardim Conduta, temos que considerar: a) diante dos imensos espaços de vazios urbanos, não é nem necessário e nem indispensável construir-se em Área de Preservação Permanente;

b) não foram realizados estudos que orientem os aterramentos que estão sendo executados no Leito Maior do Ribeirão Claro;

c) não foram realizados estudos que demonstrem os impactos ambientais, sociais e econômicos que as obras desencadearão nos locais em que estão sendo construídas;

d) não foram realizados estudos que demonstrem os impactos ambientais, sociais e econômicos que as obras desencadearão ao nível regional, afetando a bacia hidrográfica.

\section{ALGUNS QUESTIONAMENTOS}

A ocupação do Leito Maior com ruas, habitações, atividades produtoras de bens e serviços, tem acarretado muitos prejuízos às populações envolvidas. O caso da Vila Industrial em Rio Claro é um bom exemplo do uso indevido das margens fluviais, com severas consequências sociais e econômicas para a municipalidade. No caso referido a população, depois de muito sofrimento, tendo suas residências submetidas a enchentes do Córrego Cachoeirinha e do Ribeirão Claro, teve suas residências removidas para áreas topograficamente mais elevadas e livres das cheias. Contudo, até que isto acontecesse, muitos sacrifícios foram impostos à população, que foi submetida a perdas materiais (móveis e objetos de utilidades), bem como a pressão psicológica. Muitos dos ex-moradores da Vila Industrial argumentam que se sentiam tensos no trabalho ou em outro local, quando observavam no céu a preparação de chuvas. Imaginavam que seus filhose demais familiares estavam expostos aos riscos das enchentes fluviais e não sabiam que condições encontrariam em suas casas, no retorno do trabalho. No caso da Vila Industrial, houve um desvio do canal fluvial para que o loteador pudesse vender maior número de lotes, com conivência da Prefeitura Municipal de Rio Claro.

No caso do Projeto Pé-no-Chão, no Jardim Conduta, a situação é semelhante. Diariamente, dezenas de caminhões transportam entulhos, lixo doméstico, restos de podas de vegetação das ruas, lixo de posto de gasolina ou oficina mecânica, e 
depositam no Leito Maior do Ribeirão Claro, pela margem direita (FOTOGRAFIAS 2, 3 e 4). Há que se destacar que, antes do aterro, a área apresentava canais fluviais e setores alagados, do tipo pantanosos. Assim, o Ribeirão Claro está ficando com seu Leito Maior diminuído e confinado para que, sobre o referido aterro, sejam construídas as habitações do referido Projeto. Contudo, pela necessidade de expandir suas águas de cheias, o Ribeirão Claro não respeitará os limites impostos pelos aterros. Assim, nos períodos de cheias, mais dias ou menos dias, suas águas transbordarão por sobre o aterro e atingirão as habitações construídas. A montante existem represas, construídas para atividades rurais, que muitas vezes têm suas comportas abertas para "sangrar" as águas das cheias. Neste caso, a situação de insalubridade é ainda mais exacerbada do que na Vila Industrial. Poucos metros a montante, o Ribeirão Claro recebe o aporte de grande parte dos esgotos domésticos da área urbana de Rio Claro. Portanto, ao drenar a área onde está sendo edificado o Projeto Pé-noChão, no Jardim Conduta, o Ribeirão Claro possui suas águas com elevada carga de efluentes. Portanto, nos períodos de cheias - os meses com maiores riscos de cheias são: novembro, dezembro, janeiro, fevereiro e março - o Ribeirão Claro transbordará, atingindo as habitações e ruas (FOTOGRAFIA 5), contendo toda sua carga de efluentes urbanos. Disto advêm os riscos para a saúde das populações, tendo em vista as possibilidades de serem atingidas pelas doenças de veiculação hídrica, bem como por aquelas resultantes de períodos pós-enchentes.

O Plano Diretor do Município de Rio Claro, em seu Volume 2, página 153, explica o que são as Zonas de Proteção-5 (ZP-5) dizendo: "Planícies aluviais (PL) ("várzea") - são zonas de proteção ambiental - o uso dessas áreas será reservado EXCLUSIVAMENTE para fins agrícolas adequados como arroz, horticultura, pastagens, gramíneas e congêneres e de mineração, respeitada a legislação de parcelamento do solo urbano e de proteção aos mananciais e estará sob a supervisão e fiscalização da Secretaria do Planejamento e Meio Ambiente, Departamento Agrícola Municipal e CURADORIA DO MEIO AMBIENTE (Procuradoria Pública.". No Volume 1, do mesmo Plano Diretor, às folhas 162 fundamenta-se a importância da preservação dessas áreas, ao dizer-se : "...As planícies aluviais protegidas pela Lei Federal 6.766/79 (Lei Lehmann)

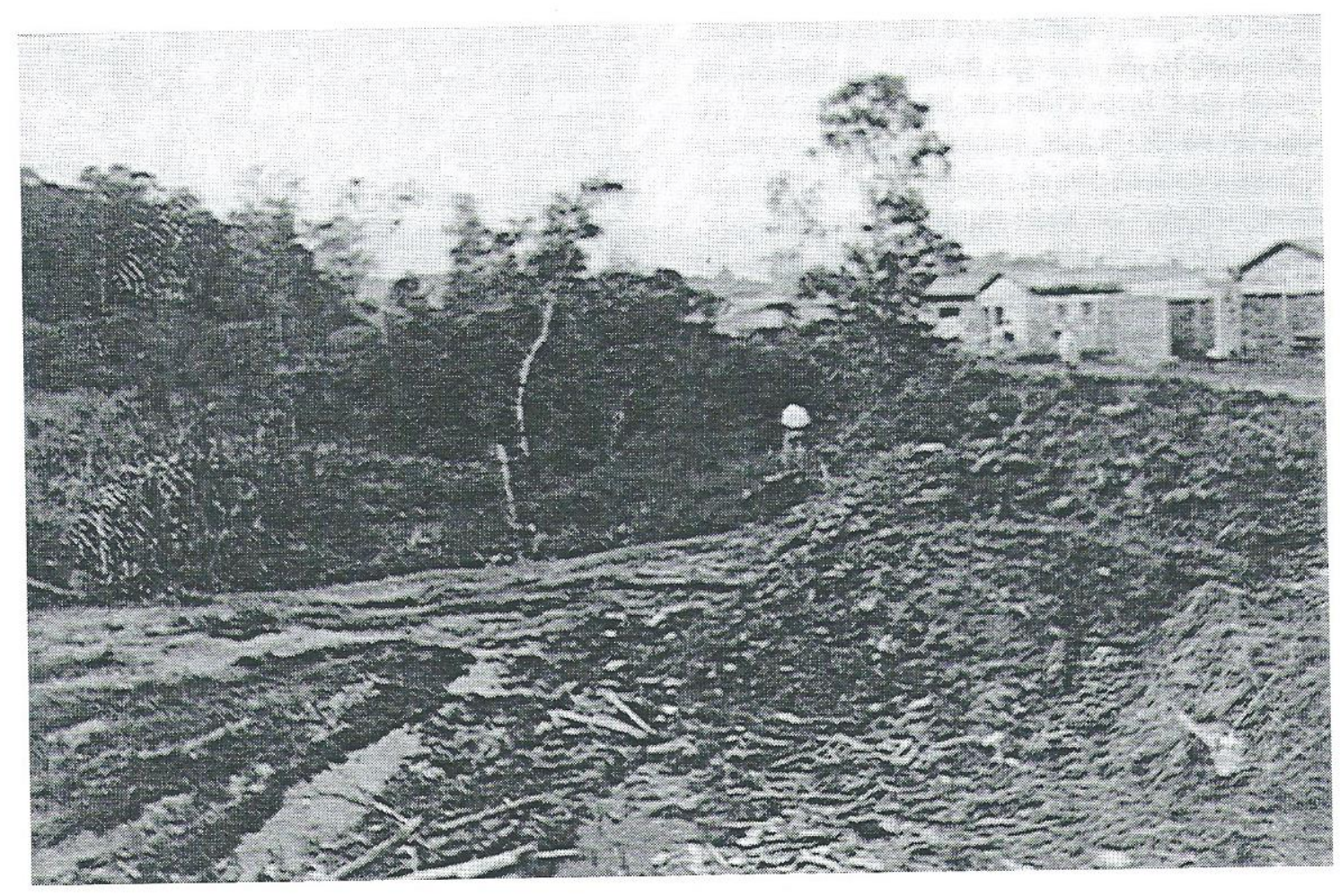

FOTO 2 - Area alagada, localizada na parte esquerda-central da fotografia, demonstra um setor remanescente da antiga lagoa, situada no leito maior do Ribeirão Claro. O aterro, observado ao centro e à direita da fatografia, entulhou por rejeitos e lixos de origens diversas a lagoa e portanto a Área de Preservação Permanente. Esse aterramento é efetuado com conivência da Prefeitura Municipal, destruíndo as áreas preservadas pelas Legislações Federal, Estadual e Lei Orgânica do Município. 


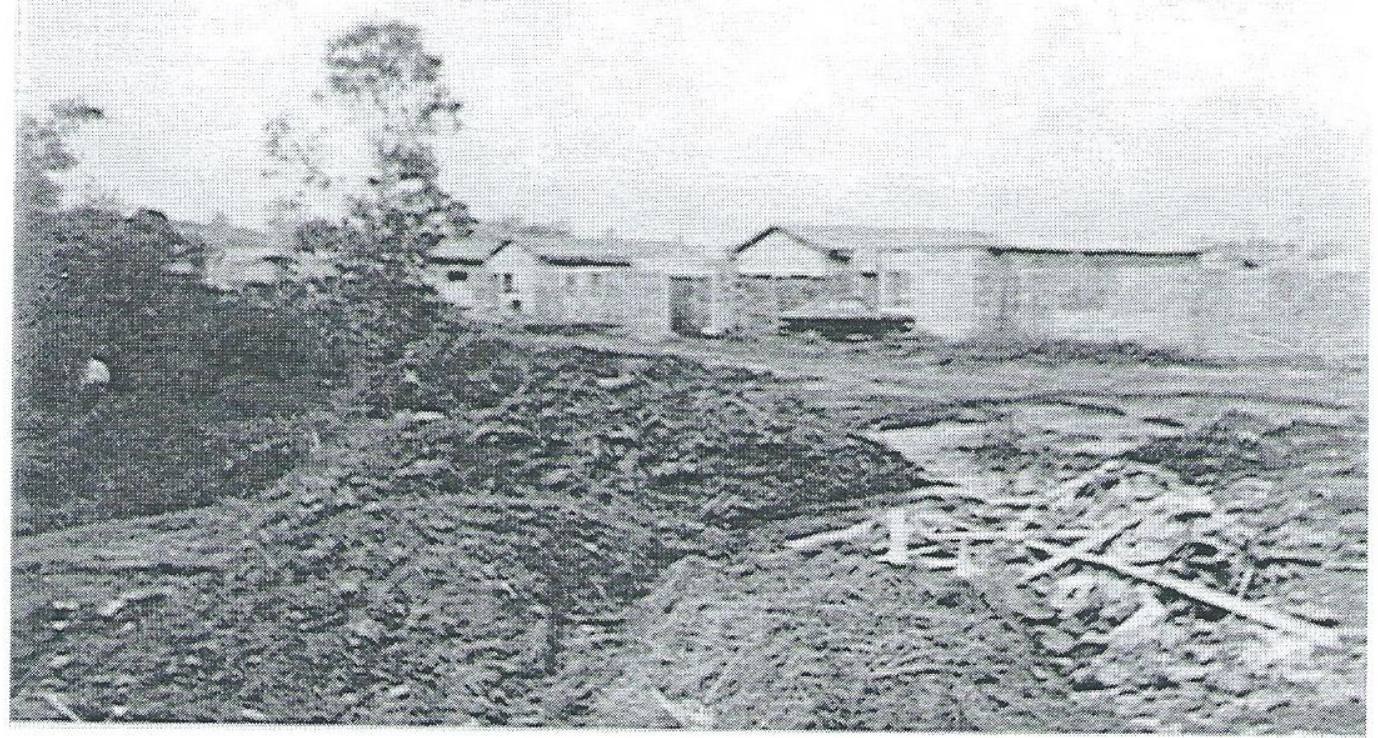

FOTO 3 - O desnivel topográfico registrado pela fotografia, demonstra que o Leito Maior do Ribeirão Claro foi aterrado com variações de $1,50 \mathrm{~m}$ a $2 \mathrm{~m}$ de entuhos, lixo doméstico, lixo de postos de gasolina e outros rejeitos de várias origens. Com isto o nível topográfico do aterro retirou as habitaçōes do setor alagado inerente à área. Contudo, o aterro não foi suficiente para remover a umidade do local, que tenderá a se manifestar em sua superfície e também será atingido pelas águas de cheias do Ribeirão Claro. Salientase a ressurgência de esgoto na várzea.

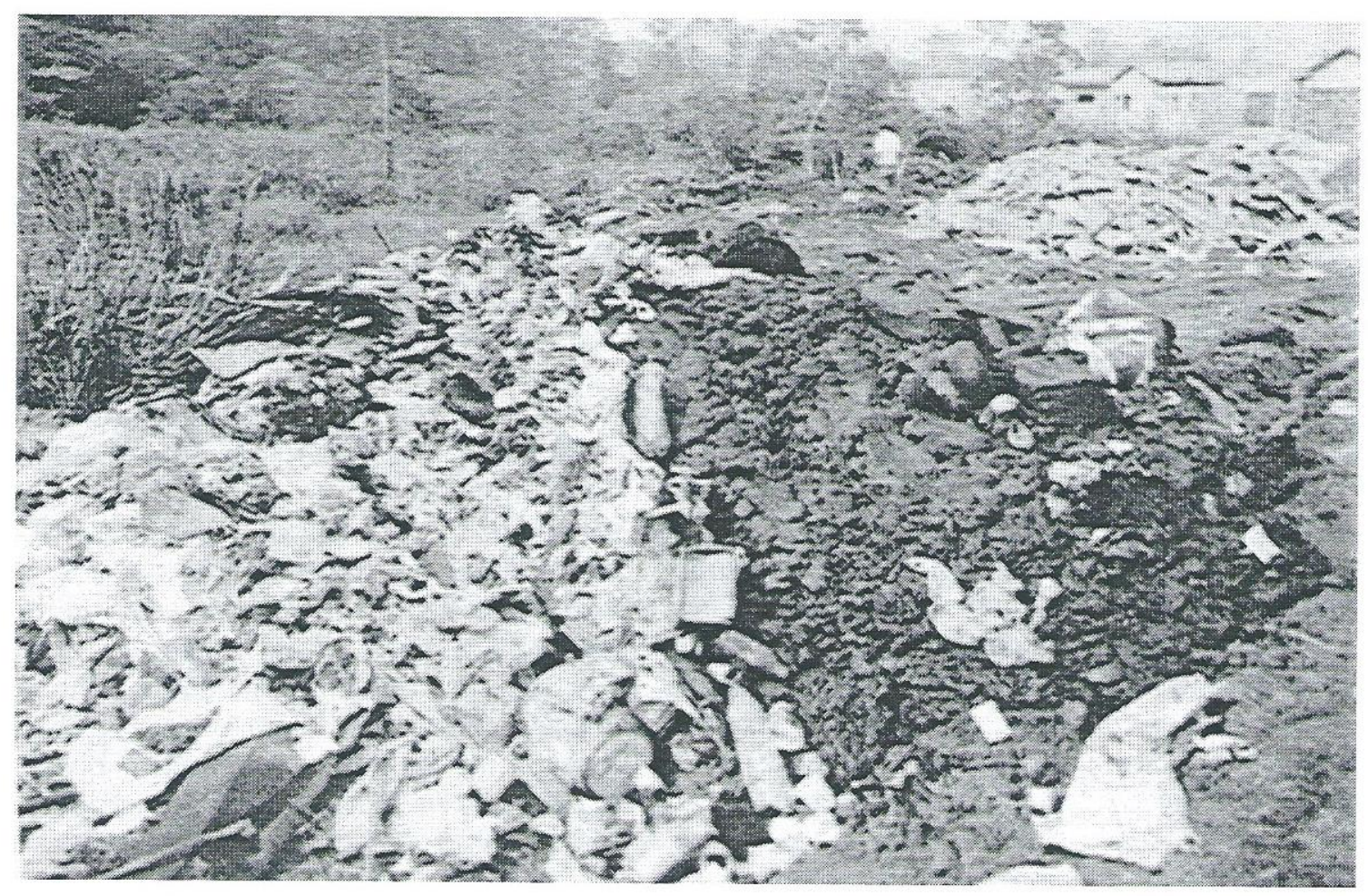

FOTO 4 - Detalhes da fotografia anterior, notando-se os rejeitos de postos de gasolina e lixo doméstico depositados para efeito de aterramento. Na parte esquerda-central registram-se individuos de vegetação higrófila (taboa), indicando a característica "pantanosa". 


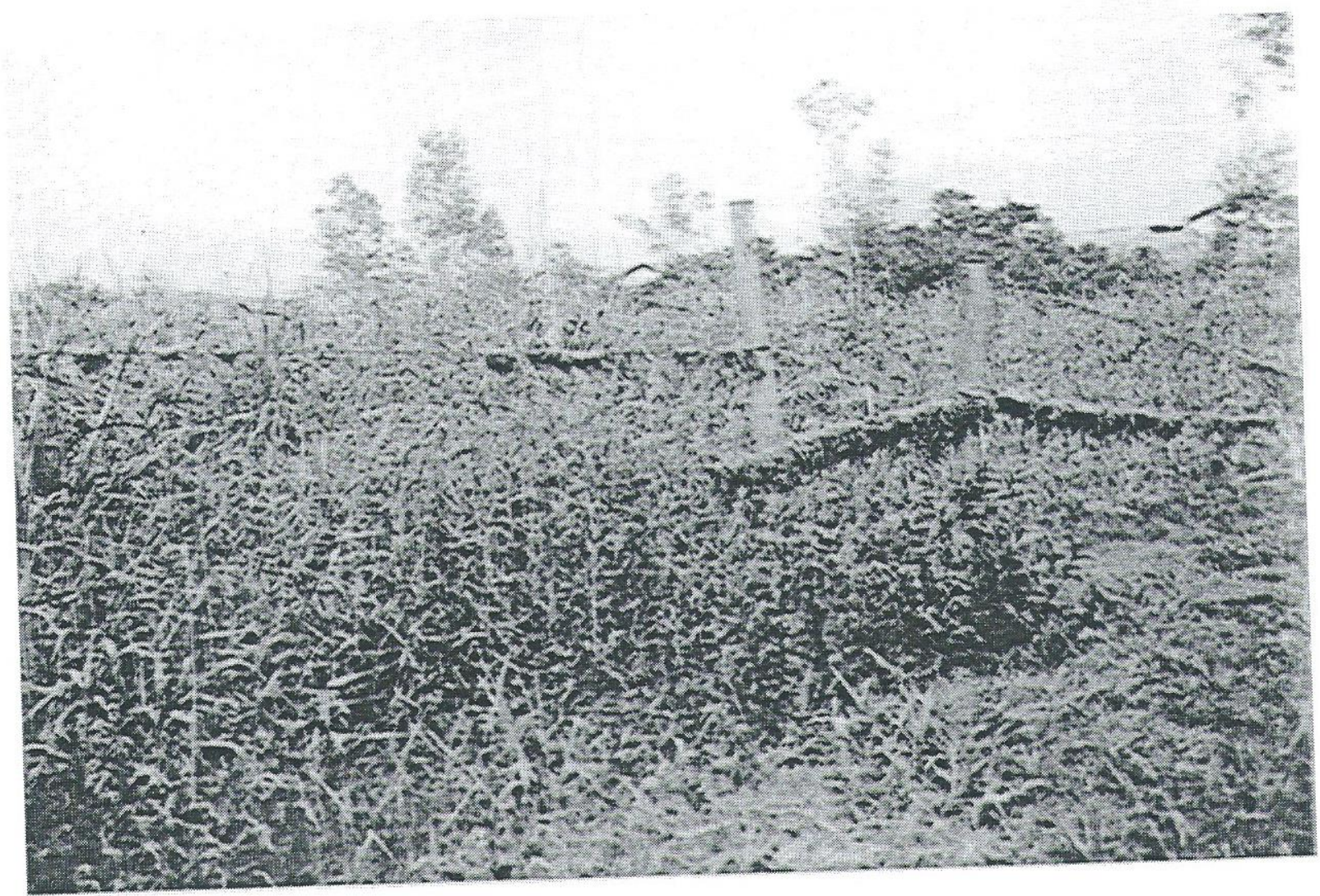

FOTO 5 - A cerca com mourōes de madeira e arame farpado ficou marcada pela matéria orgânica transportada pelas águas de enchentes. É uma comprovação de que as cheias do Ribeirão Claro atingem cerca de 1,50m sobre o piso da planície fluvial, pertencente ao Leito Maior.

correspondem ao Leito Maior do rio, ou leito de inundação ou ainda várzea (nome popular). Elas podem atingir dezenas ou até centenas de metros de extensão, e são limitadas de cada lado por um degrau topográfico (terraços) na base das encostas. Esses terraços, de 4 a 6 metros acima das planícies, indicam a zona onde termina a várzea e onde se iniciam os terrenos secos das encostas.". Mais à frente, na mesma página, diz o documento: "...O Município de Rio Claro, tanto na bacia do Ribeirão Claro como do Corumbataí há problemas de impacto, comprometendo as várzeas e infringindo leis federais, estaduais e municipais. Grande parte dos loteamentos da periferia da cidade aproximouse ou invadiu as várzeas, destruindo a mata galeria, penetrando também nas zonas de nascentes (anfiteatros), onde se originam os pequenos córregos, afluentes dos rios-principais. Todos esses pontos estão mapeados como áreas de risco ocupadas pela expansão urbana desordenada". A FIGURA 2 apresenta um trecho do Mapa (D.II.3) do Plano Diretor demonstrando que o Projeto Péno-Chão, no Jardim Condutta, está dentro de ZP-5 e ZP-30. A FIGURA 3 apresenta a ilustração do
Plano Diretor de Rio Claro, Volume 2, Folhas 111, com uma demonstração didática do Leito Maior e sua determinação como Área de Preservação Permanente. O modelo apresentado pela FIGURA 4 é absolutamente pertinente ao caso do Projeto Pé-no-Chão, Jardim Conduta.

MACHADO (1991), analisando as Exigências Fundamentais para a Admissão do Parcelamento do Solo Urbano, afirma: "Não será permitido o parcelamento do solo em terrenos alagadiços e sujeitos a inundações, antes de tomadas as providências para assegurar o escoamento das águas. Da mesma forma o terreno sujeito a inundação ou situado à beira de cursos d'água e que periodicamente é invadido pelas cheias, não poderá ser loteado. Locais onde as águas pluviais se acumulam, onde não haja escoamento devido, somente poderão ser loteados se corrigida a situação. Evita-se, portanto, agrupar indivíduos em locais inundáveis, com 0 consequente perigo para a vida e saúde da população e com resultados danosos para a economia dos compradores. Será uma tarefa 
Figura 2 - Situação da Área do Projeto PÉ NO CHĀO no jardim Condutto Rio Claro-SP (1995)

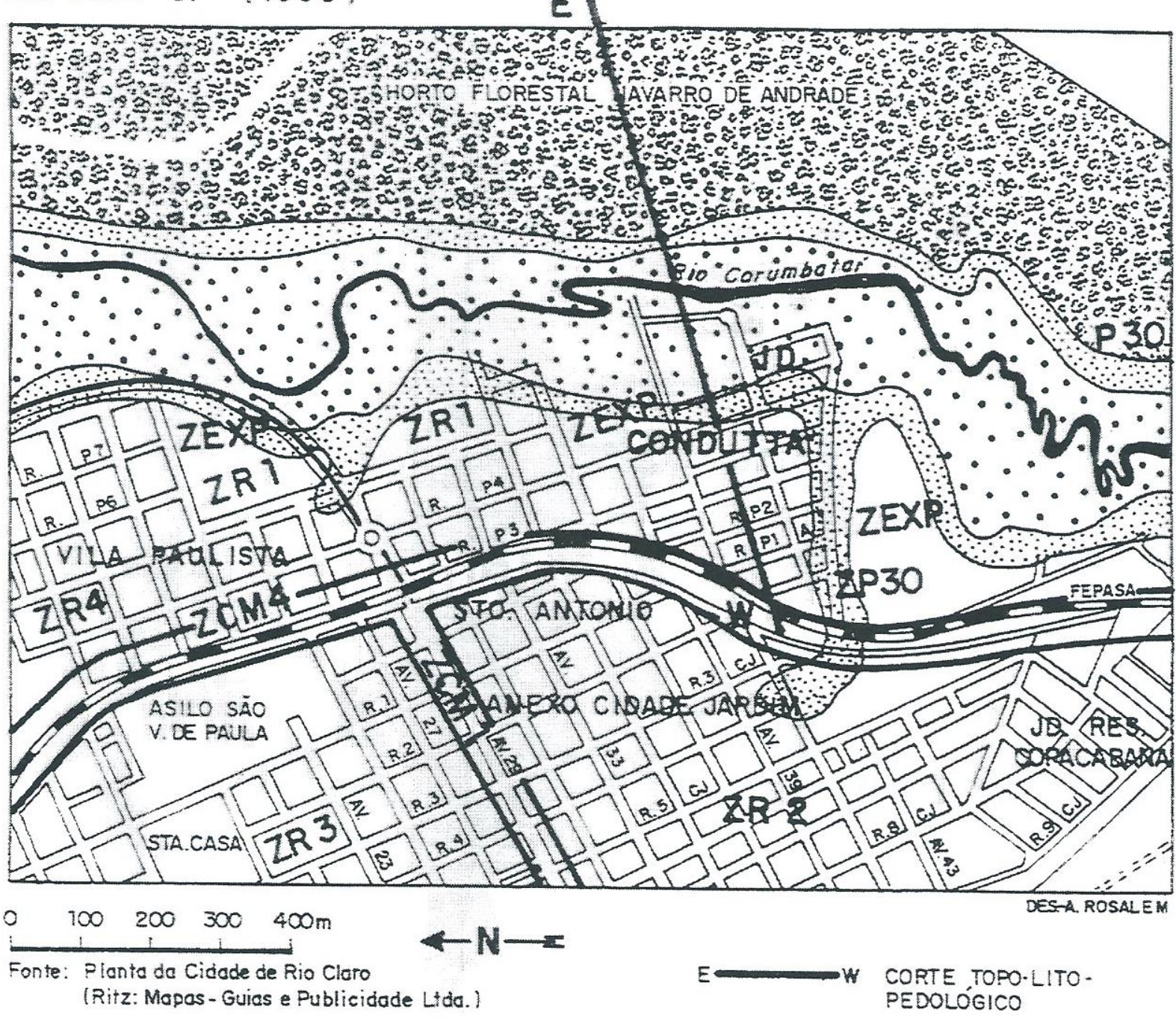

\section{LEGENDA}

SITIO URBANO DE RIO CLARO E BACIA DO CORUMBATAII PLANICIES ALUVIAIS E ZONAS DE ENTORNO PROTEGIDAS PELAS LEIS DEPROTEC ĀO AOS MANANCIAIS E DO PARCELAMENTO DO SOLO URBANO

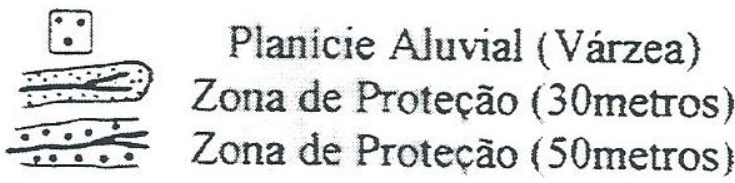

$\begin{array}{cc}\text { PERIMETRO URBANO PROPOSTO } \\ \text { ZEXP } & \text { Zona de Expanção } \\ \text { ZP } & \text { Zona de Proteção } \\ \text { ZCM } & \text { Zona Comercial } \\ \text { ZR } & \text { Zona Residencial }\end{array}$

Adaptado do Plano Diretor de Desenvolvimento Integrado de Rio Claro 


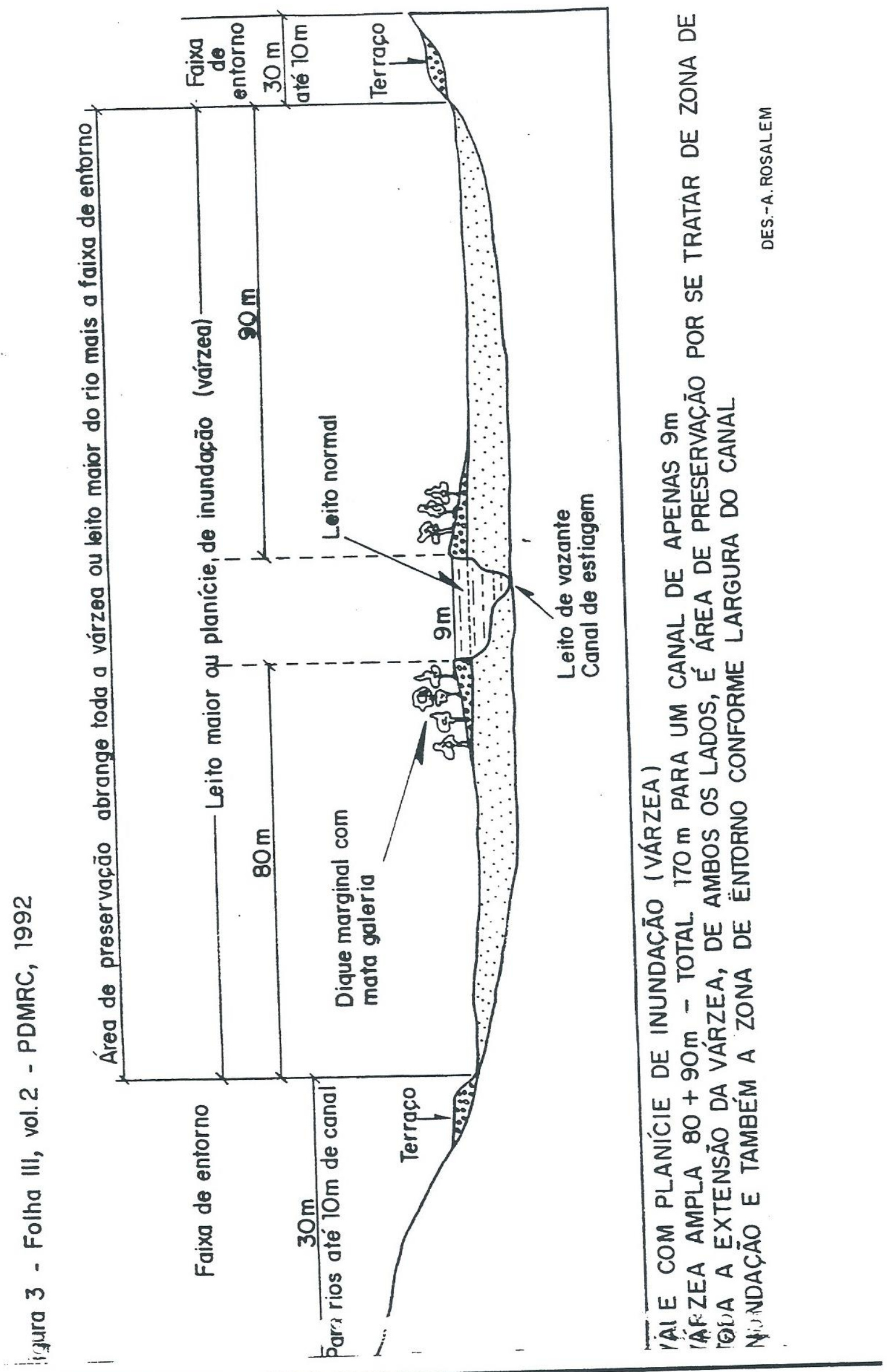


técnica avaliar, através de laudo motivado, a possibilidade ou não de as águas terem escoamento ou de as inundações atingirem o local que se pretende urbanizar". No caso do Projeto Pé-noChão, no Jardim Conduta, as análises do Perfil Topo-lito-pedológico apresentado (FIGURAS 1, 2, 3 e 4), as análises das Fotografias Aéreas levantadas em 1969, na Escala 1: 8.000 pela VASP e através das observações de campo confirmam que a área é Leito Maior do Ribeirão Claro, portanto sujeita a inundações.

É interessante que se busque conhecer o que pensam autoridades que administram municípios onde a situação ambiental se aproxima da condição catastrófica, nos momentos em que ocorrem as chuvas concentradas $e$ os transbordamentos fluviais. Veja-se por exemplo o que afirma MALUF (1993) "A vulnerabilidade ambiental de São Paulo, no que se refere ao solo, decorre da ocupação inadequada de áreas de potencial paisagístico relevante; do aumento da taxa de erosão decorrente da falta de cobertura vegetal, do uso de técnicas inadequadas de terraplenagem, de pavimentação e infra-estrutura incompletas; do crescimento do número de focos de inundação, causados pela impermeabilização do solo, sistema de drenagem incompleto ou insuficiente e a ocupação inadequada de várzeas e fundos de vale.". Essas experiências acumuladas na Capital do Estado de São Paulo certamente são vivenciadas em outras cidades, e não se deve permitir a repetição dos mesmos erros em Rio Claro.

Diante dos fatos pode-se resumir assim o quadro apresentado:

a) a área é inadequada para construções de habitações;

b) não houve os mínimos cuidados para saneá-la;

c) a tecnologia necessária para sanear a área e/ou para um projeto construtivo que colocasse as habitações fora do "risco de inundações" implica em elevados custos financeiros, incompatíveis com o destino que se pretende oferecer para a área; diríamos, ainda, que um estudo técnico apropriado custaria mais que a aquisição de terras adequadas para o projeto; outrossim, a remoção das casas deverá apresentar um custo menor do que qualquer medida paliativa; d) a Área de Preservação Permanente e o próprio Leito Maior ("várzea") do Ribeirão Claro foram e continuam sendo afetados;

e) a Prefeitura Municipal e a Câmara Municipal tinham conhecimentos sobre as Leis Federais e Estaduais, aprovaram e promulgaram as Leis Municipais que impediam as construções.

\section{ABRANGÊNCIA DO PROBLEMA DA OCUPAÇÃO DE VÁRZEAS}

A área está situada no próprio leito do Ribeirão Claro, mais precisamente no seu leito maior (FOTOGRAFIA 6), conforme TRICART(1966). CHRISTOFOLETI (1981) afirma que o "...leito maior periódico ou sazonal é regularmente ocupado pelas cheias, pelo menos uma vez por ano...". Porisso, quando se fala da margem do rio, não se pode considerar aquela que corresponde ao leito de vazante fluvial, como muito bem explica o Código Florestal, ao disciplinar que as áreas de preservação permanente se relacionam ao nível alto das águas, portanto, ao leito maior. Desta forma, a área onde estão sendo construídas as casas do Projeto Pé-noChão, do Jardim Conduta, diz respeito a um alagado, onde aflora o lençol freático (FOTOGRAFIA 6), através de nascentes e/ou "olhos d'água" e que no período de cheias é atingida pelo Ribeirão Claro. Trata-se portanto de uma Área de Preservação Permanente, que foi aterrada para receber as edificações e continua sendo soterrada, ou aterrada.

- Mapa do Plano Diretor de Desenvolvimento de Rio Claro- Prancha P-02, Lei Municipal 2495/92 (vide FIGURA 3, extraído do mapa editado pela "Ritz: Mapas - Guias e Publicidade Ltda.) assinalou a área em questão, como Área de Preservação Permanente, impedida de receber construções. Essa argumentação é enriquecida por ORELLANA (1991), ao afirmar que "...se o canal normal tem até 9 metros, mas possui uma planície de inundação de 100 metros de extensão, a faixa de proteção de 30 metros deverá ser contada a partir da borda externa do leito maior ("várzea") ou seja, a partir do terraço. Nesse caso aplicam-se as duas leis: a de proteção dos mananciais Lei $7.511 / 86$ e a Lei $6.766 / 79$ do parcelamento do solo urbano, que proíbe a ocupação das "várzeas".". Essa concepção foi muito corretamente incorporada no Plano Diretor de Desenvolvimento de Rio Claro. 


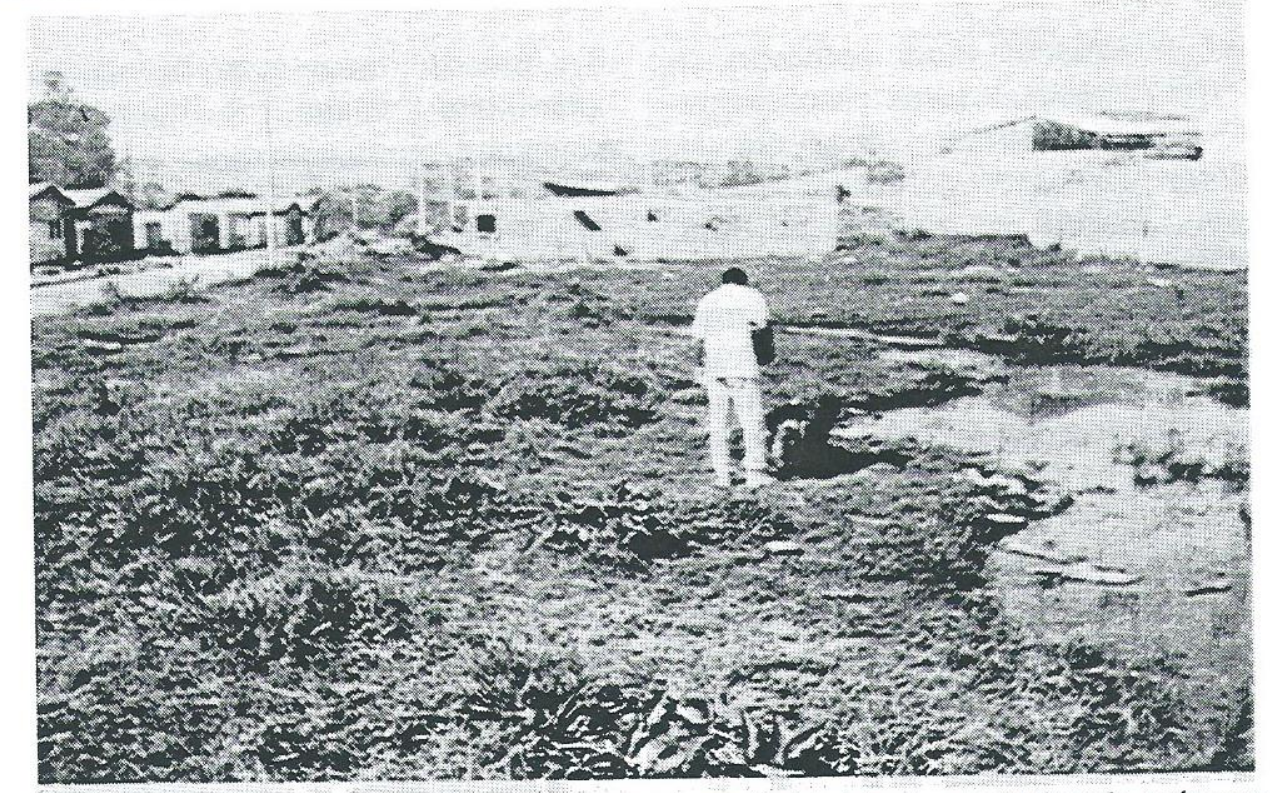

FOTO 6 - Área alagada com "olho d'água" natural. Destaque-se que a fotografia foi efetuada no mês de maio, após uma sequência de dias sem chuvas. O Projeto Pé-no-Chão está sendo construído entre esta área alagada e o leito de vazante do Ribeirão Claro. $\mathrm{O}$ destaque da área alagada é confirmativo de que a área aterrada pertence ao Leito Maior do Ribeirão Claro.

Fica claro que o Projeto Pé-no-Chão do Jardim Conduta não se apresenta distante da margem do Ribeirão Claro, mas, dentro da área de sua inundação, ou seja, em seu Leito Maior. Segundo o Mapa do Plano Diretor (op. cit.), a área foi classificada como ZP-5, onde o uso é permitido apenas para fins de preservação.

\section{CARACTERIZAÇÃO FISIOGRÁFICA DA ÁREA}

O referido projeto situa-se na "várzea" do Ribeirão Claro, assim, nos períodos de chuvas, a área se caracteriza por ser o próprio curso do ribeirão. Nas estiagens sazonais, quando a gleba não está completamente submersa, surgem os cursos secundários, os setores alagados e, portanto, os afloramentos permanentes d'água (FOTOGRAFIAS 6 e 7). Apesar da área estar superficialmente descaracterizada pelos aterros ilegais e pelo Projeto Pé-no-Chão, a dinâmica fluvial deste setor em várzea mantém-se. A área está submetida às variações dos níveis de água dos setores de montante, tanto do Leito Menor quanto do Leito Maior, nos períodos de estiagens e de cheias. Além disto, a área está sujeita aos períodos críticos de secas e cheias, com intensidade maior do que as médias diárias/anuais. Nos episódios críticos de chuvas, quando ocorrem grandes intensidades de precipitações em poucos minutos ou horas, ou mesmo em períodos com duração prolongada das chuvas, a área fica sujeita a cheias consideradas anormais, que podem ir inclusive além do seu leito maior (FOTOGRAFIA 4). Nessas condições, há fundamentação técnica nos dispositivos legais que preservam essas áreas da ocupação. É indispensável que a sociedade civil e o Poder Público protejam as Áreas de Preservação Permanente, evitando assim os prejuízos econômicos e sociais advindos das enchentes, alcançando residências.

O Leito Maior constitui-se num armazenador, e porisso mesmo, num controlador das águas das enchentes, servindo portanto de área para a expansão das águas fluviais de cheias. Para exercer essa função referida - armazenador das águas das enchentes - o Leito Maior não pode ser aterrado e não pode ser submetido a edificações.

Desta forma, na gleba que foi aterrada para construção do Projeto Pé-no-Chão no Jardim Conduta, há cursos de água e olhos d'água dos tipos:

a) nos períodos de cheias habituais: a área se constitui no próprio curso do Ribeirão Claro, conjugando as águas do escoamento fluvial e aquelas das precipitações pluviais;

b) nos períodos de estiagem a área apresenta alguns setores alagados e outros se caracterizam como nascentes fluviais e/ou "olhos d'água". 


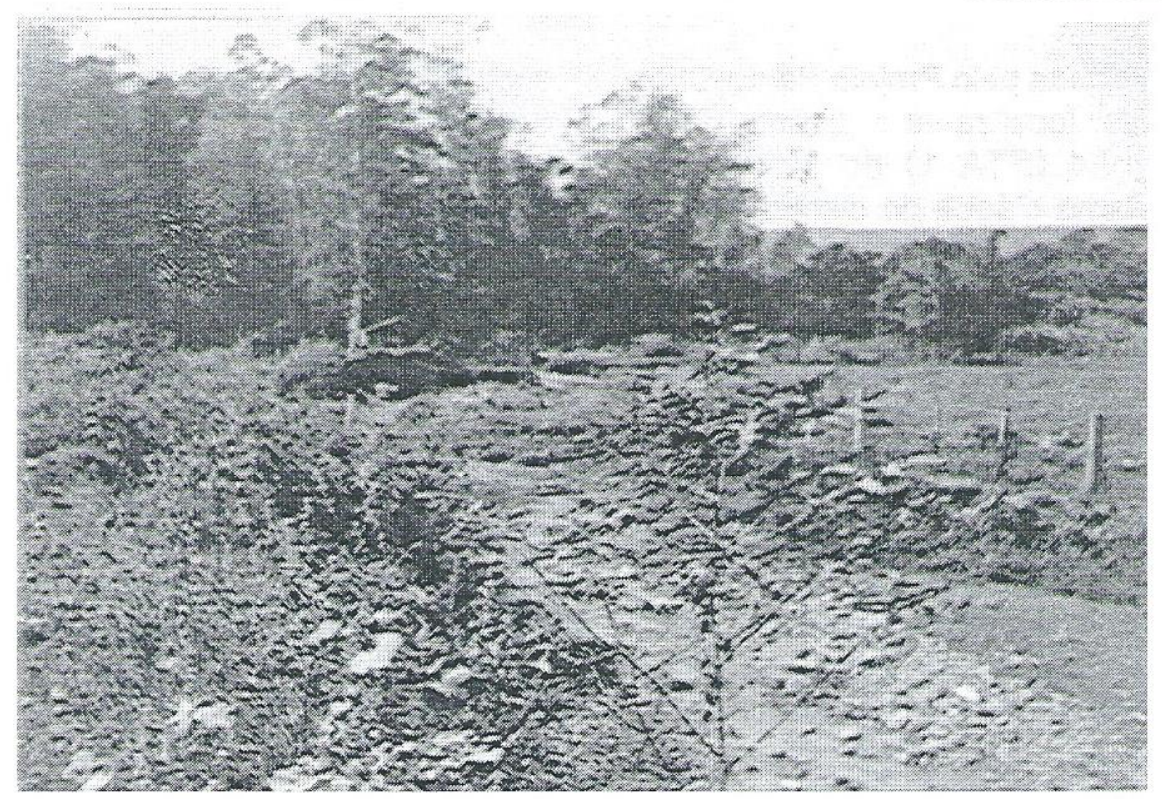

FOTO 7 - Um setor onde se pretende ampliar o Projeto Pè-no-Chāo è contiguo aos aterros mostrados. Parte dessa área, delimitada pelo Córrego ilustrado na fotografia, também apresenta características de inundaçōes. Neste caso as inundações são conjugadas pelas águas deste Córrego com as do Ribeirāo Claro, ampliadas pelo escoamento pluvial.

Apesar desses "corpos d'água" terem sido soterrados, contudo, a médio prazo poderão ressurgir, afetando drasticamente as construções e principalmente, gerando um ambiente úmido e insalubre para as populações que ocupariam as casas. A FOTOGRAFIA 6 é demonstradora de que pequenas escavações no solo alcançam o nível de água, e, em alguns pontos, ela aflora na superfície sem que haja necessidade de abertura de valas para assentamento de alicerces. Mais do que isso, as cheias maiores deverão atingir a superfície do aterro que recebeu as construções.

Entendem-se como áreas alagadas aquelas que acusam presença de água mesmo durante os meses de baixa pluviosidade, como por exemplo setores "pantanosos" e pequenos lagos. As FOTOGRAFIAS 2 e 6 exemplificam áreas alagadas. Por áreas inundáveis entendem-se aquelas que nos períodos de chuvas são atingidas pelas águas das cheias, do escoamento pluvial, e também aquelas que ficam submersas, com a abertura de comportas de barragens e/ou pequenas represas. As duas classificações -alagadas e inundáveis- são adequadas para o Leito Maior do Ribeirão Claro, no setor em questão.

Deve-se ressaltar que áreas como estas, ou seja, de Preservação Permanente, são de interesse social, para proteção dos recursos naturais, resultando em benefícios para toda a sociedade; assim definiram a Lei Federal, a
Constituição do Estado de São Paulo e a Lei Orgânica do Município. Torna-se agravante o fato de que os Poderes Municipais (Executivo e Legislativo) elaboraram e aprovaram as leis locais, suportados em argumentos técnicos, portanto, com absoluta consciência da necessidade de preservas - Leito Maior do Ribeirão Claro e seus afluentes. Portanto, seria impossível a atribuição de título de propriedade aos cidadãos que ali construírem suas habitações, a menos que se pratiquem ainda outras irregularidades, ao arrepio da legislação e com conivência geral.

As áreas alagadas e as inundáveis, destinadas à Preservação Permanente, conforme - Plano Diretor de Desenvolvimento de Rio Claro, estarão sendo desafetadas para atribuir-Ihes outro uso, ou seja, uso residencial.

Além disto todos os corpos d'água municipais, tanto aqueles localizados a montante como a jusante de seu ponto de captação para abastecimento urbano, são seus mananciais. Ocorre que os corpos d'água de um município, além de servirem para o sistema de abastecimento urbano, são também utilizados para outras atividades, inclusive para uso na produção agropecuária e mesmo para o consumo dos moradores ribeirinhos. Assim, o Ribeirão Claro é manancial do município, desde sua nascente até sua foz. 
A gleba utilizada pelo Projeto Pé-no-Chão, no Jardim Conduta, localiza-se a jusante de um ponto de captação (ETA 1) do sistema de abastecimento urbano d'água do distrito sede de Rio Claro. Ressalte-se que o Ribeirão Claro, a jusante, constitui-se no divisor Municipal de Rio Claro e Santa Gertrudes, estando sujeito a imposições especiais da Constituição do Estado de São Paulo. Logo mais adiante, o Ribeirão Claro desemboca no Rio Corumbataí, drenando o distrito de Assistência (zona urbana e rural), cuja população rural se utiliza dessas águas para práticas agropecuárias e recreativas. Ademais, o Ribeirão Claro e o Rio Corumbataí fazem parte da bacia hidrográfica do sistema Piracicaba-Capivari, gerenciado por um Consórcio do qual o Município de Rio Claro faz parte. O Município de Piracicaba necessita captar a água do Rio Corumbataí para complementar o abastecimento de seu distrito sede e outros distritos e bairros rurais.

A implantação do Projeto Pé-no-Chão gera prejuízos ao manancial. A impermeabilização de uma grande parte da "várzea" do Ribeirão Claro, com aterramento e construções, causa danos ao manancial, uma vez que interfere na capacidade de armazenamento d'água e regulação do fluxo fluvial, modificando a vazão das cheias e/ou chuvas críticas e das estiagens regulares e/ou críticas. $O$ aterramento, preenchendo com entulhos a "várzea", diminui o espaço de inundação do rio. A partir dessa intervenção no Leito Maior exige-se do canal fluvial uma capacidade de drenar, com maior velocidade, para remover as águas que se precipitam, nas partes altas e médias da bacia hidrográfica. Contudo, com o aumento da impermeabilização, aumenta o fluxo de águas que aportam ao canal fluvial nos períodos de chuvas. Haveria necessidade de aumentar-se a velocidade do escoamento fluvial para que o canal tivesse capacidade para suportar a vazão ampliada, sem promover inundações. Para solucionar esse problema não há qualquer previsão e projeto desenvolvido pela Prefeitura. Esse conflito, gerado pelas obras, deverá aumentar as possibilidades de ocasionar cheias e inundações a montante do Projeto Pé-no-Chão, no Jardim Conduta. Por outro lado, a redução do espaço de inundação e, portanto, de armazenamento das águas de cheias, acarretará uma diminuição na disponibilidade de água no período da estiagem -principalmente nos meses de maio, junho, julho, agosto, setembro e outubro. As águas armazenadas pelas "várzeas" e pelo lençol subterrâneo alimentaram os rios nos períodos de estiagem, e esta é exatamente uma das características do Ribeirão Claro.

PINTO (1993), apresentou dados demonstrativos de que o Ribeirão Claro é regular em sua vazão, durante todo o ano. Essa regularidade foi interpretada como consequência do trabalho armazenador das águas, exercido por rochas, solos e "várzeas". As águas das chuvas ficam armazenadas e alimentam o ribeirão nos períodos das estiagens. Contudo, obras de impermeabilização, principalmente afetando o Leito Maior, modificam as características de infiltração, afetando o curso fluvial, gerando prejuízos ao escoamento superficial e portanto ao manancial.

Entendendo-se o abastecimento no sentido mais amplo, incluindo as propriedades rurais que dependem dessas águas para o consumo de seus animais e outros usos, as obras prejudicam o abastecimento municipal. Em geral, os incorporadores imobiliários e demais infratores contra o meio ambiente argumentam que pequenas obras não são responsáveis pelas mudanças de comportamento do escoamento fluvial. Contudo, há que se reconhecer que a somatória e a interrelação das pequenas obras acarretam sérios prejuízos aos cursos d'água. Esse tipo de obra contribui para o agravamento das crises ocasionadas em períodos de estiagens regulares e críticas, afetando principalmente as atividades rurais que dependem das águas do Ribeirão Claro e Rio Corumbataí. Efeitos dessas interferências negativas nos mananciais já têm sido sentidos no abastecimento d'água urbano no distrito sede do Município. No final de 1994, por exemplo, o Departamento Autônomo de Água e Esgoto (DAEE) de Rio Claro teve que desenvolver uma campanha para redução de consumo doméstico, chegando ao racionamento, para evitar piores consequências com a falta de água.

\section{QUANTIFICAÇÃO DOS PROBLEMAS GERADOS}

Em geral, os prejuízos produzidos contra o meio ambiente apresentam dificuldades para serem quantificados, mas isto é possível. Entre os elementos que precisam ser considerados, levamse em conta: os prejuízos produzidos com a destruição da vegetação da Área de Preservação 
Permanente; os prejuízos com aterramento da referida área; as obras de edificação realizadas no local; os prejuízos produzidos com a remoção do material depositado indevidamente; os prejuízos produzidos com a reabilitação da área, retornandoa para a função natural. Portanto, os danos e prejuízos produzidos são quantificados com base no cálculo do custo do trabalho necessário à recomposição/reabilitação da área segundo prescrição da Constituição Federal (inciso I, dos Parágrafos $1^{\circ}$ e Parágrafo $3^{\circ}$ do artigo 225), além do ressarcimento dos gastos públicos e dos gastos privados relativos à construção das moradias. Os custos dos impactos futuros exigem estudos mais detalhados para quantificá-los. A maior dificuldade está no dimensionamento do valor do meio ambiente degradado pela atividade. Isto pelo fato de não existirem parâmetros muito eficientes para se dizer qual é o preço que se deve pagar pela contaminação da água, do solo e da vegetação, legados pela natureza sem custo financeiro para a humanidade. Em geral, o preço que deve ser pago pelos bens naturais é inestimável.

A implantação do referido Projeto deverá agravar a situação de uma área situada a montante que já apresenta problemas de escoamento das águas pluviais. Famílias que moram no Jardim Conduta, em níveis topográficos mais elevados do que aqueles referentes ao Projeto Pé-no-Chão, narram os refluxos de esgotos para dentro de suas casas, nos períodos de chuvas, quando o Ribeirão Claro apresenta-se com suas águas mais elevadas. Isto ocorre em função dos desníveis topográficos que são pequenos, havendo dificuldades de escoamento das águas e dos esgotos. Com a subida dos níveis do Ribeirão Claro, suas águas barram as partes terminais dos tubos coletores e emissários de esgotos, provocando o refluxo para dentro de casas. As obras de aterramento executadas (FOTOGRAFIAS 2,3 e 4), impermeabilizando e modificando o leito de escoamento do Ribeirão Claro, deverão ampliar a incidência desses refluxos.

\section{CONSIDERAÇÕES FINAIS E CONCLUSÕES}

Deste modo, técnica e legalmente, a única alternativa para se resolver o problema dos alagamentos e restaurar os danos causado ao meio ambiente (área do Projeto e vizinhança) é remover as casas, remover o aterro, incluindo os entulhos colocados anteriormente no terreno e nas suas imediações. Caso contrário a área se constituirá num ponto crítico de inundações, com todas as consequências para as famílias residentes no lo$\mathrm{cal}$, a montante e a jusante. Neste momento as famílias estão ansiosas por conquistar uma moradia, "fechando os olhos" aos perigos de riscos (o "abafamento da consciência" leva a um "comportamento esquizóide" da população, segundo Jameson, Lacan in Harvey, 1992) para os quais as pessoas estão sendo dirigidas. Algumas donas de casa entrevistadas no local demonstram que não possuem renda mensal para continuar pagando aluguéis de moradia. Porisso, necessitam urgentemente de um local para morar, mesmo que haja perigo de risco (esta expressão tem conotação jurídica. Aquele que gera o perigo de risco age de forma criminosa, mesmo que até o presente momento nenhuma pessoa tenha sido afetada diretamente). Contudo, o Poder Público não pode ignorar os problemas que estará causando a essas famílias. Tendo em vista que a legislação foi elaborada pelo Poder Público (legislativo e executivo municipais), não há como declarar desconhecimento. Providenciar as obras em uma área impedida por Lei tem a agravante de se constituir num descompromisso com o Código de Defesa do Consumidor. Há uma nítida manifestação de "má fé" ao se estimular e dar meios para que uma população ocupe o Leito Maior, pensando que resolverá seu problema habitacional. Como a Prefeitura Municipal de Rio Claro utilizou o Projeto Pé-no-Chão para fazer propaganda da administração, efetuou no saguão do Paço Municipal, uma exposição de suas plantas urbanísticas e construtivas. Deve-se salientar que o projeto do Jardim Conduta sequer participou dessa exposição. Do mesmo modo, não foi explicitado o nome do técnico responsável, devidamente habilitado pelo CREA, em qualquer dos projetos expostos. Viabilizam-se, assim, lucros privados às custas da socialização difusa dos prejuízos. Todas as obras futuras de urbanização (pavimentação, drenagem urbana, infra-estrutura de água e esgoto etc.) apresentarão custos mais altos. De fato, a realidade é que estão sendo criadas as circunstâncias problemáticas para o futuro próximo, de médio e longo prazos.

Além dos riscos constantes de inundação, dos prejuízos trazidos para os mananciais e outros componentes do meio ambiente, as casas estarão sempre sujeitas à insalubridade inerente aos espaços úmidos; umidade que se caracterizará em 
constante motivo para o comprometimento da saúde das pessoas. Considere-se ainda que as inundações trarão os esgotos já referidos, e que são lançados no Ribeirão Claro, com todas as suas implicações para a saúde pública.

Acrescentam-se ainda alguns pontos que devem ser levados em conta. É comum que sejam ouvidas opiniões, fundamentadas no aspecto social da questão, afirmando que uma vez ocorrido o dano ambiental, desfazer o que foi feito seria agravar uma situação social sem nenhuma compensação ao meio ambiente. Essa argumentação é totalmente falsa, na medida em que está estimulando o desrespeito à legislação e incentivando o oferecimento das piores áreas para serem habitadas pelos setores sociais mais empobrecidos. Esta, inclusive, é a argumentação dos infratores que, ao arrepio dos dispositivos legais, desconsideram as demonstrações que contrariam o interesse de implantar Projetos, como o que está em tela. Em geral, essas autoridades contam com a lentidão da Justiça e com a possibilidade de impunidade para seus atos. Notase que no caso do Projeto Pé-no-Chão, no Jardim Conduta, joga-se com o destino da população mais desfavorecida, provocando uma comoção social, para viabilizar todos os desmandos legais e administrativos. Um exemplo dessa expectativa de contar com a impunidade é ilustrada pelas atitudes do Secretário Municipal de Habitação. O referido Secretário, em diálogo com docentes e discentes, concordou com todas as argumentações aqui apresentadas. Apesar disso não tomou medidas para interromper as atividades ali desenvolvidas, permitindo que a situação se aprofunde e se agrave. Pelo contrário, o aterramento da "várzea", das vizinhanças do Projeto foi intensificado, com a utilização de material inadequado, incluindo despejos de postos de gasolina (FOTOGRAFIA 4). Presumidamente, a intenção da Prefeitura Municipal, através dessa atuação, é tornar a situação irreversível, ganhando novas áreas para ampliar o número de casas, e por consequência ampliando o problema. Contudo, este plano só se tornará viável se a sociedade optar pela impunidade dos responsáveis que relegam o bem-estar das pessoas e os recursos públicos envolvidos.

Constata-se assim que as autoridades (executivo e legislativo municipal): conheciam o impedimento legal para construção de habitações na área, são assessoradas por profissionais do melhor gabarito, no trato das questões ambientais urbanas; reconhecem o perigo de risco iminente, seja de inundação e alagamento da área, seja de comprometimento da saúde pública. Diante disto, não há justificativas para as situações criadas, como aquelas existentes no Projeto Pé-no-Chão, no Jardim Conduta. Assim, a população que foi contemplada com as habitações deve receber uma outra área, com adequadas condições sanitárias. Todos os custos de materiais e tempo investidos pela população devem ser restituídos, para que ela nada perca, e possa realizar seu "sonho" de adquirir a "casa própria".

Há também, por parte da Prefeitura Municipal, a intenção de aumentar o número de casas do projeto no Jardim Conduta, conforme se verificou em atividades de campo. Os aterramentos (com entulho e lixo) no setor do Leito Maior, localizados a montante da atual área e os trabalhos de agrimensura a jusante, onde se verifica a presença de córregos, confirmam esta previsão (FOTOGRAFIA 7).

\section{BIBLIOGRAFIA}

CHRISTOFOLETTI, A (1981) - Geomorfologia Fluvial. Ed. Edgard Blücher, USP, São Paulo, 313 p.

COOKE,R. U. \& DOORNKAMP,J. C. (1990) - Geomorphology in Environmental Management. Edt. Claredon Press, Oxford, $410 \mathrm{p}$.

HARVEY,D. (1992) - A Condição Pós-Moderna. Edições Loyola. São Paulo.

MACHADO,P. A. L. (1991) - Direito Ambiental Brasileiro. Edição Editora Revista dos Tribunais Ltda., 3a. edição. São Paulo, 595 p.

MALUF,P. (1993) - Apresentação, In Questão Ambiental Urbana. Prefeitura Municipal de São Paulo. pp. 17-20, São Paulo.

ORELLANA, M. M.. P. (1991) - Mapeamento de Zonas de Proteção Ambiental: Aplicação de Conceitos Geomorfológicos na Interpretação da Legislação. Boletim de Geografia Teorética, 21 (41): 149-153. Rio Claro.

PINTO,A. L. (1993) - Estudo da Potencialidade, Captação, Tratamento, Abastecimento e 
Potabilidade da Água da Bacia do Ribeirão Claro (SP). Dissertação de Mestrado, IGCE/UNESP. Rio Claro, 263 p. Inédito.

PREFEITURA MUNICIPAL DE RIO CLARO (1992). Plano Diretor do Município de Rio Claro. Rio Claro. Inédito.
TRICART,J. L. (1966) - Os Tipos de Leitos Fluviais. Notícia Geomorfológica, 6(11): 41-49. Campinas.

ZAINE,J. E. (1995) - Geologia da Formação Rio Claro, na Folha Rio Claro (SP). Dissertação de Mestrado, IGCE/UNESP. Rio Claro. Inédito. 